\title{
First Isolation and Molecular Characterization of bla CTX-M-121 -producing Escherichia coli 0157:H7 Strain Y4-A109 from Cattle in China
}

\section{Zhanqiang Su}

Xinjiang Agricultural University

Panpan Tong(Former Corresponding Author)

Xinjiang Agricultural University https://orcid.org/0000-0002-0027-4437

\section{Ling Zhang}

Xinjiang Agricultural University

\section{Mengmeng Zhang}

Xinjiang Agricultural University

\section{Dong Wang}

Xinjiang Agricultural University

\section{Kaiqi Ma}

Xinjiang Agricultural University

\section{Yi Zhang}

Xinjiang Agricultural University

Yingyu Liu

Xinjiang Agricultural University

Lining Xia

Xinjiang Agricultural University

Jinxin Xie(New Corresponding Author) ( $\square$ xiejinxin198683@163.com )

Xinjiang Agricultural University

\section{Research article}

Keywords: E. coli 0157:H7, virulence genes, antibiotic resistance, PFGE, bovine

Posted Date: March 9th, 2020

DOI: https://doi.org/10.21203/rs.2.18636/v2

License: (c) (1) This work is licensed under a Creative Commons Attribution 4.0 International License. Read Full License 


\section{Abstract}

Background: To study the antibiotic resistance, the molecular epidemiology of bovine Escherichia coli ( E.coli ) 0157:H7, and exploring the intrinsic relationship among different isolates, we have collected 27 bovine E. coli 0157:H7 strains in Xinjiang from 2012 to 2017 and evaluated virulence genes, antibiotic resistance, and pulsed-field gel electrophoresis (PFGE) molecular typing.

Results: Of all the 27 bovine E. coli 0157:H7 strains analyzed, 21 strains contained at least one virulence gene, 19 strains carried eae gene (70.4\%) and 8 of them carrying stx $1+$ stx $2+$ eae + hly + tccP. Most strains were sensitive to all the antibiotics tested. However, 4 of which were antibiotic-resistant, and 2 of which possessed multi-drug resistance, including one ESBL-producing strain. This is the first report of the bla CTX-M-121 gene in bovine E. coli 0157:H7. Moreover, the bla CTX-M-121 gene can be transmitted horizontally through plasmid between strains. The similarity of PFGE spectra of 27 strains was between

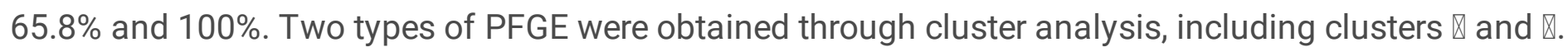

Conclusions: E. coli 0157:H7 may have undergone clonal propagation in cattle farms as well as crossregional transmission and horizontal transmission in different regions in Xinjiang China.

\section{Background}

E.coli $0157: \mathrm{H} 7$ is a major foodborne pathogen that causes severe bloody diarrhea, hemorrhagic colitis, and hemolytic uremic syndrome in humans [1]. E. coli 0157: $\mathrm{H} 7$ was first recognized as a pathogen in an investigation of an outbreak of hemorrhagic colitis associated with hamburger consumption in 1982 [2]. Since then, many outbreaks of E. coli 0157:H7 infection have been reported in the United States, Canada, Japan, and China [3-6]. Cattle is reported to be the major reservoir and source of infection for $E$. coli 0157:H7. E. coli 0157:H7 from healthy cattle has been reported worldwide [7]. The infected cattle irregularly excreted E. coli 0157:H7 without any pathological symptom, and transmitted the pathogen to humans through food, water, direct contact with animals or the environment [8].

The pathogenicity of $E$. coli $0157: \mathrm{H} 7$ is associated to genes encoding for multiple virulence factors. Shiga toxins (stx) is one of the major virulence factors involved in the pathogenesis of E. coli 0157:H7 and is encoded by the $s t x 1$ or stx 2 genes [9]. Intimin and enterohemolysin (encoded by the eae gene and the hly gene, respectively) are two other markers that play a major role in pathogenesis [9]. The tccP protein encoded by the $t c c P$ gene is a pathogenic molecule of $E$. coli $0157: \mathrm{H} 7$ and is transduced into host cells through the type III secretion system to exert its pathogenic effect [10]. These genetic virulence characteristics are commonly used in epidemiological studies of strains from various origins $[6,11]$.

Undoubtedly, antimicrobia are the main tool for the prevention and treatment of bacterial diseases in animals. However, antibiotic resistance has become a serious problem worldwide, especially in developing countries where the quality, distribution and use of antibiotics in human medicine and veterinary medicine are not strictly controlled [11, 12]. Diseases caused by E.coli usually require antimicrobial treatment, but antibiotic-resistant strains of this bacterium may cause more chronic and more severe diseases than their 
antibiotic-susceptible counterparts [12]. E. coli 0157: $\mathrm{H} 7$ strains isolated from humans and animals have been resistant to a variety of antibiotics [13]. The emergence of multi-drug resistant (MDR) E. coli 0157:H7 is a public health issue.

Xinjiang has one of China's largest cattle raising industry. Effective prevention and control of bovine pathogenic microorganisms is a prerequisite to ensure the healthy and sustainable development of the cattle industry and consumer safety. To further assess the potential public health impact of $E$. coli 0157:H7 isolates, we investigated the pathogenicity and antibiotic resistance of these strains originating from farms and slaughterhouses, and examined the intrinsic relationship among different isolates and assessed the potential dissemination of MDR profiles in vitro.

\section{Results}

\section{Isolation of $E$. coli 0157:H7}

A total of 27 E. coli 0157:H7 strains were isolated from 2,657 cattle samples in Xinjiang, 2 of which were collected from one carcass swab sample, 4 from 3 feed samples, 8 from 8 feces samples and 13 from 5 rectal swab samples, and multiple colonies were selected from the same plate (Table 1).

\section{Presence of virulence genes}

Of the 27 E. coli 0157:H7 isolates tested, 21 isolates carried more than one virulence genes, and $6(22.2 \%)$ did not encode the genes evaluated in the study. Polymerase chain reaction (PCR) showed that $2(7.4 \%)$ isolates carried $s t \times 1,8(29.6 \%)$ possessed $s t \times 2$, and $8(29.6 \%)$ contained both $s t x 1$ and $s t \times 2$. The eae gene and $h l y$ gene were detected in most (70.4\%) and 17 (63.0\%) E. coli 0157:H7 strains, respectively. TccP in combination with $h l y$ and eae was found in $15(55.6 \%)$ isolates, st $x 2$ alone and eae alone were present in $2(7.4 \%)$ isolates (Table 1$)$.

\section{Antibiotic resistance spectrum and distribution of antibiotic resistance genes}

Twenty-three (85.2\%) E. coli 0157:H7 isolates were sensitive to all of antimicrobials investigated. Four isolates $(14.8 \%)$ were resistant, 3 of which were isolated from the same cattle farm in Yili. Of the four resistant isolates, 2 were only resistant to tetracycline, and one of which carries tet $A$ gene that encodes a tetracycline efflux pump. The other two were MDR strains with the resistant patterns:

AMP/CHL/CIP/CTX/LEV /PIP/SXT/TET (Y4-C21-1) and AMP/CAZ/CHL/CIP/CTX/LEV/PIP/SXT/TET (Y4A109). In particular, the ones with the Y4-A109 was an Extended Spectrum Beta-Lactamases (ESBLs)producing strain and carrying the b/a $a_{\mathrm{CTX}-\mathrm{M}-121}$ gene.

\section{Transferability of bla $a_{\mathrm{CTX}-\mathrm{M}}$ genes and plasmid replicon typing}

The bla $a_{\mathrm{CTX}-\mathrm{M}}$ gene of E. coli 0157:H7 isolate (Y4-A109) was transferred to the recipient strain (azideresistant $E$. coli J53) by conjugation at frequencies of $10^{-6}$ per donor cell. Resistance to ampicillin, cefotaxime, ceftazidime, trimethoprim- sulfamethylisoxazole and tetracycline, and resistance to the 
bla $a_{\mathrm{CTX}-\mathrm{M}-121}$ gene from the b/a $a_{\mathrm{CTX}-\mathrm{M}}-$ producing 0157:H7 isolate can be transferred to the recipient. The $b / a_{\text {CTX-M-121 }}$ gene is carried by non-typeable plasmid.

\section{Epidemiological typing}

The chromosomal DNA of 27 isolates was available for PFGE typing and the isolates showed 14 different PFGE profiles (Fig. 1). The similarity among the types was higher than $65.8 \%$, with the two dominant clusters I and II accounting for $40.7 \%$, and $18.5 \%$, respectively. Cluster $\otimes$ mainly includes type $\mathrm{p} 4$, and

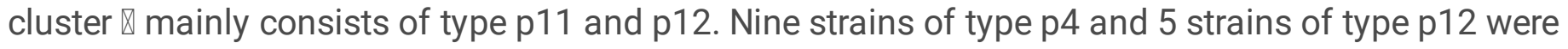
highly consistent in sampling time and location, which was determined as clonal propagation. Significant differences were found between $p 4$ and p12 strains ( $p$ value?) with isolates were collected in different regions and years. Four drug-resistant bacterial strains belong to four different types.

\section{Discussion}

E. coli $0157: \mathrm{H7}$ is an important foodborne pathogen [1]. Cattle is considered to be the major reservoir and transmitting diseases to humans primarily by eating contaminated food. In this study, a total of 2,657 cattle sourced samples were collected from Tacheng ( 2 farms), Bole ( 1 farm), Yili (4 farms and 1 slaughterhouse), Wujiaqu (1 farm), Changji (2 farms), Wulumuqi (4 farms) and Akesu (4 farms), 27 E. coli 0157:H7 strains were isolated. E. coli 0157:H7 was isolated from Yili, Wulumuqi and Akesu, while not from Tacheng, Bole, Wujiaqu and Changji, which indicated the presence of regional differences in bacterial distribution. We discovered that the number of $E$. coli $0157: \mathrm{H} 7$ isolates were low in winter and high in summer, which is consistent with the previous finding [14]. In addition, the number of E. coli 0157:H7 isolates were lower in Xinjiang when compared to other provinces in China $[6,15]$. Our previous studies have shown that the immunomagnetic separation (IMS) in practice was not statistically significant different compared to conventional method [16]. The low isolation rate of E. coli 0157: $\mathrm{H} 7$ may be related to the severe dry weather conditions of Xinjiang, which needs further confirmation.

The pathogenicity of $E$. coli $0157: \mathrm{H} 7$ is associated with several virulence factors, including the production of Shiga toxins (stx1 and/or stx2), intimin (eae), enterohemolysin ( $h l y)$ and tir couple cytoskeleton protein $(t c c P)$. The results showed that $37.0 \%$ and $59.3 \%$ of $E$. coli $0157: \mathrm{H} 7$ isolates contain stx 1 and stx 2 genes, respectively. Epidemiological researches have shown that the virulence of $s t \times 2$-producing strains is higher than st $x$ producers [17]. The eae gene which is necessary for the attaching and effacing activity encodes an intimin protein that is essential for pathogenesis [18]. In our study, this important virulence gene was detected in $70.4 \%$ of the E. coli $0157: \mathrm{H} 7$ isolates. We identified the $t c c P$ gene in $55.6 \%$ of the E. coli 0157:H7 strains. Noticeably, tccP gene is highly correlated with both eae gene and $h / y$ gene, but not with the stx gene.

Although the sample size in the slaughterhouse is small, the isolation rate of carcass swab samples was higher than others samples from the cattle farms, and one of which was the MDR bacteria, which showed co-selection evidence of antibiotic resistance and virulence. In this study, two E. coli 0157:H7 isolates were found to be resistant against new and more clinically important antimicrobial compounds such as 
fluoroquinolones and cephalosporins. Beta-lactamases production is the main mechanism underlying the cephalosporin resistance in Gram-negative bacteria [19]. Broad-spectrum cephalosporins are important drugs in both human and veterinary medicine. We investigated various narrow-spectrum (b/a $\mathrm{T}_{\mathrm{TEM}}$ and $\left.b / a_{\mathrm{SHV}}\right)$ and extended-spectrum ( $\left.b / a_{\mathrm{CTX}-\mathrm{M}}\right) \beta$-lactamase-encoding genes, but only identified one- $b / a_{\mathrm{CTX}-\mathrm{M}}$. This is the first report of the bla $a_{\mathrm{CTX}-\mathrm{M}-121}$ gene in bovine $E$. coli 0157:H7. The tet $A$ is one of the most widespread tet genes found in Enterobacteria [20], and is the only tetracycline resistant gene identified in four tetracycline-resistant strains. However, to our knowledge, this is the first report about the presence of tet $A$ in bovine $E$. coli 0157:H7 in Xinjiang. Conjugative transfer of non-typeable plasmid was observed. Conjugation experiments successfully transduced MDR to $\beta$-lactamases, sulfonamides and tetracycline. This study highlights the importance of encouraging the appropriate use of antibiotics.

The dendrogram analysis of the PFGE results showed that the two E. coli 0157:H7 strains isolated from the same carcass swab samples from the slaughterhouse belonged to clusters I and II, suggesting that cross-contamination may occur during the slaughter process. The Y4-A20-1, Y4-A20-3, Y4-A20-4 of cluster $\mathrm{I}$, and Y4-A20-5 of cluster II from the same rectal swab, indicates that different E. coli 0157:H7 strains have been colonized in cattle. Cluster I W1-E51-5 and cluster II W1-E51-3F were isolated from the same feed sample, suggesting that the cattle farm feed was contaminated with different $E$. coli 0157:H7 strains. Cluster II Y1-166 and Y3-F328 were isolated from different cattle farms in the same region at the same time, which further proved the horizontal transmission was an important means of E. coli 0157:H7 dissemination in these farms. Cluster I Y4-A20-1, W2-A61-2 and W1-E51-5, and cluster II Y2-F25, A1-F13 and A2-F14 were isolated at different time points and from different regions. These cattle farms were separated far away. Cross-regional transmission of bacteria may be caused by trading in live animals. Based on the analysis of virulence genes and drug resistance of $E$. coli 0157:H7, we speculate that virulence and drug resistance may be acquired or lost during the evolution and transfer of the same cluster of strains.

\section{Conclusions}

In this study, E. coli 0157:H7 contamination was found in cattle farms and slaughterhouse in Xinjiang, and most isolates carried at least one virulence gene. E. coli 0157:H7 may have undergone clonal propagation in cattle farms and transmitted horizontally in different regions.

\section{Methods}

\section{Sample collection}

Samples ( $n=2657$ ) were collected from 18 farms and one cattle slaughterhouse in Tacheng, Bole, Yili, Wujiaqu, Changji, Wulumuqi and Akesu in Xinjiang of China between October 2012 and March 2017, including 1155 fresh feces, 1236 rectal swabs, 110 feed, 108 water and 48 carcass swabs (Table 2).

\section{Bacterial isolate}


Each $1 \mathrm{~g}$ or $1 \mathrm{ml}$ sample (feces/feed/water) were aseptically added to $9 \mathrm{ml}$ of trypticase soya broth (TSB) containing $20 \mathrm{mg} / \mathrm{l}$ novobiocin and were incubated for $6-8 \mathrm{~h}$ at $37^{\circ} \mathrm{C}$. A rectal swab was transferred into a separate tube containing $2 \mathrm{ml}$ nutrient broth and cultured at $37^{\circ} \mathrm{C}$ for $24 \mathrm{~h} \mathrm{[21].} \mathrm{One} \mathrm{carcass} \mathrm{swab} \mathrm{was} \mathrm{put}$ into a stomacher bag and added $500 \mathrm{ml}$ of modified trypticase soya broth containing $8 \mathrm{mg} / \mathrm{l}$ novobiocin. Each sponge was mixed in the stomacher bag for $2 \mathrm{~min}$ and then incubated for $20 \mathrm{~h}$ at $37^{\circ} \mathrm{C}$ [22]. This was streaked out onto Sorbitol MacConkey agar supplemented with $0.01 \mathrm{mg} / \mathrm{l}$ cefixime and $0.5 \mathrm{mg} / \mathrm{l}$ potassium tellurite (Haibo, Qingdao,China) (CT-SMAC) and incubated for one day at $37^{\circ} \mathrm{C}$. One or more pale colonies were individually selected as presumptive E. coli 0157 per sample. The prevalence of $E$. coli 0157:H7 was assessed via polymerase chain reaction (PCR) (rfbE and fliC genes [23]) (Table 3). The positive isolates were each inoculated into separate TSB and incubated for one day at $37^{\circ} \mathrm{C}$, from which glycerol stock was made and then stored at $-80^{\circ} \mathrm{C}$ for further analysis.

\section{Virulence analysis of isolates}

DNA extraction

DNA was extracted by boiling the isolates. Each colony was inoculated on CT-SMAC and incubated for 16 h at $37^{\circ} \mathrm{C}$ to obtain fresh colony. Several colonies were selected and suspended separately in $200 \mu \mathrm{l}$ of sterile distilled water in $1.5 \mathrm{ml}$ eppendorf tubes. The suspensions were then boiled at $95^{\circ} \mathrm{C}$ for $10 \mathrm{~min}$ in a water bath. After centrifuging at $12000 \mathrm{rpm}$ for $10 \mathrm{~min}$, the supernatant containing the template DNA was transferred into $1.5 \mathrm{ml}$ Eppendorf tubes without nuclease and were stored at $-20^{\circ} \mathrm{C}$ until use.

Determination of virulence genes by PCR

To characterize the virulence genes, amplification products of stx 1 , st $x 2$, eae, $h l y$ and $t c c P$ genes were used, which encode for Stx1, Stx2 toxins, intimin, enterohemolysin, and tir couple cytoskeleton protein respectively. The primers, conditions and references cited are listed in Table 3. Amplification of the targeted gene used EX Taq (TaKaRa, Dalian, China) with the following PCR program: $94{ }^{\circ} \mathrm{C}$ for 4 min, 30 cycles of denaturation at $94{ }^{\circ} \mathrm{C}$ for $30 \mathrm{~s}$, annealing at $54{ }^{\circ} \mathrm{C}$ for $30 \mathrm{~s}$, and extension at $72{ }^{\circ} \mathrm{C}$ for $30 \mathrm{~s}$, with a final extension at $72{ }^{\circ} \mathrm{C}$ for $10 \mathrm{~min}$. Adjust annealing temperature according to primer Tm value (Table 3). The PCR amplicons $(10 \mu \mathrm{l})$ were subjected to electrophoresis on a $1.2 \%$ agarose gel in $1 \times$ TAE buffer at $115 \mathrm{~V}$ for $30 \mathrm{~min}$, and stained with SYBR Green (Fermentas, Germany).

\section{Antimicrobial susceptibility tests}

The susceptibility of to antibiotics was tested using the Kirby-Bauer disc diffusion technique. Antibiotic discs obtained from OXOID, UK, including ampicillin (AMP), piperacillin (PIP), cefotaxime (CTX), ceftazidime (CAZ), cefepime (FEP), aztreonam (ATM), ampicillin-sulbactam (SAM), piperacillintazobactam (TZP), amoxicillin-clavulanic acid (AMC), gentamicin (GEN), amikacin (AMI), streptomycin (STR), trimethoprim-sulfamethylisoxazole (SXT), chloramphenicol (CHL), levofloxacin (LEV), ciprofloxacin (CIP), tetracycline (TET), and polymyxin B (PB) [26]. E. coli ATCC25922 was used as a quality control strain in the susceptibility tests. The ESBLs-producing isolates were determined by double-disk synergy tests according to CLSI [26]. 


\section{Detection of antibiotic resistance genes}

The following resistance determinants were investigated by PCR: bla ${ }_{\mathrm{CTX}-\mathrm{M}}$ (the CTX-M-type genes were detected using universal primers bla ${ }_{\mathrm{CTX}-\mathrm{M}-\mathrm{U}}[27]$, and the entire CTX-M-type genes were amplified using the primers b/a $a_{\mathrm{CTX}-\mathrm{M}-1 \mathrm{G}}$ [27], b/a $a_{\mathrm{CTX}-\mathrm{M}-2 \mathrm{G}}[28]$ or $b / a_{\mathrm{CTX}-\mathrm{M}-9 \mathrm{G}}$ [29]), b/a $a_{\mathrm{TEM}}[30]$, and $b / a_{\mathrm{SHV}}$ [30] which encode $\beta-$ lactamases; chloramphenicol (cm/A1 [31]) efflux pumps; sulfonamide resistance gene (sul1 [32]); and the tetA [33], tetE [33], and tetG [33] tetracycline efflux pumps. Primer for the different genes are listed in (Table 3). Purified PCR products were sequenced. The DNA sequences and deduced amino acid sequences were compared with sequences reported in GenBank to confirm the subtypes of the $\beta$-lactamase gene.

\section{Conjugation experiments and plasmid analysis}

Sodium azide-resistant $E$. coli $\mathrm{J} 53$ was used as a recipient and conjugated to a $b / a_{\mathrm{CTX}}{ }^{-} \mathrm{M}^{-}$producing isolate by filtration. Transconjugants were selected on Mac Conkey agar containing cefotaxime or ceftazidime (4 $\mu \mathrm{g} / \mathrm{ml})$ and sodium azide $(200 \mu \mathrm{g} / \mathrm{ml})$. ESBLs and antibiotic susceptibility were also tested in selected transconjugants, and the presence of bla genes was determined using PCR as described above. The resistance plasmids carried by transconjugants were typed by using PCR-based replicon typing [34].

\section{Epidemiological typing}

All available isolates were characterized by pulsed field gel electrophoresis (PFGE) using the CHEF-MAPPER System (Bio-Rad Laboratories, Hercules, CA, USA) as described by Gautom [35]. Briefly, chromosomal DNA of E. coli 0157:H7 isolate was isolated and the inserts were digested with Xbal (TaKaRa Dalian, China) for $16 \mathrm{~h}$ at $37^{\circ} \mathrm{C}$. The electrophoresis was performed at $6.0 \mathrm{~V} / \mathrm{cm}$ for $18.5 \mathrm{~h}$ with an angle of $120^{\circ}$ at $14^{\circ} \mathrm{C}$. The pulse time was increased from 0.5 to $60 \mathrm{~s}$. The Salmonella serotype Braenderup H9812 (ATCC BAA-664) was chosen as the molecular weight marker. Gels were then stained in ethidium bromide $(1.0 \mathrm{mg} / \mathrm{L})$. The results were interpreted according to the criteria of Tenover et al. [36].

\section{Abbreviations}

AMC: Amoxicillin-clavulanic acid

AMl: Amikacin

AMP: Ampicillin

ATM: Aztreonam,

CAZ: Ceftazidime

CHL: Chloramphenicol

CIP: Ciprofloxacin 
CT-SMAC: Sorbitol MacConkey agar containing cefixime and potassium tellurite

CTX: Cefotaxime

E.coli: Escherichia coli

ESBLs: Extended Spectrum Beta-Lactamases

FEP: Cefepime

GEN: Gentamicin

IMS: immunomagnetic separation

LEV: Levofloxacin

MDR: Multi-drug resistant

PCR: Polymerase chain reaction

PFGE: Pulsed-field gel electrophoresis

PB: Polymyxin B

PIP: Piperacillin

SAM: Ampicillin-sulbactam

STR: Streptomycin

stx. Shiga toxins

SXT: Trimethoprim-sulfamethylisoxazole

TET: Tetracycline

TSB: Trypticase soya broth

TZP: Piperacillin-tazobactam

\section{Declarations}

\section{Ethics approval and consent to participate}

The study was carried out on private land, no specific permissions were required for these locations. Sampling and publication of the data were approved by the farm owners. All procedures performed on the cattle were approved by the Animal Care and Use Committee of Xinjiang Agricultural University. 


\section{Consent for publication}

Not applicable.

\section{Availability of data and materials}

Not applicable.

\section{Competing interests}

The authors declare that they have no competing interests.

\section{Funding}

Funding for this study was provided by National Natural Science Foundation of China (31960695 and 31560485), Natural Science Foundation of Xinjiang Uygur Autonomous Region (2019D01A51), Prior Period Project of Xinjiang Agricultural University (XJAU201703), and by Postdoctoral Science Foundation of Xinjiang Agricultural University and Xinjiang Uygur Autonomous Region High-Level Talent Introduction.

\section{Authors' Contributions}

Z.Q.S. and P.P.T. conceived and designed the experiments. L.Z., M.M.Z., D.W., and K.Q.M. performed the experiments. Y.Z. and Y.Y.L. analyzed the date. P.P.T., L.N.X., and J.X.X. contributed to the writing of the manuscript. All authors read and approved the article.

\section{Acknowledgments}

The authors thank Xiaoli Du of State Key Laboratory for Infectious Disease Prevention and Control National Institute for Communicable Disease Control and Prevention, China CDC for her support.

\section{References}

1. Wang L, Qu K, Li X, Cao Z, Wang X, Li Z, et al. Use of bacteriophages to control Escherichia coli 0157:H7 in domestic ruminants, meat products, and fruits and vegetables. Foodborne Pathog Dis. 2017;14:483-93.

2. Riley LW, Remis RS, Helgerson SD, McGee HB, Wells JG, Davis BR, et al. Hemorrhagic colitis associated with a rare Escherichia coli serotype. N Engl J Med. 1983;308(12):681-5.

3. Ostroff SM, Kobayashi JM, Lewis JH. Infections with Escherichia coli 0157:H7 in Washington State. The first year of statewide disease surveillance. JAMA. 1989; 262:355-9.

4. Orr P, Lorencz B, Brown R, Kielly R, Tan B, Holton D. An outbreak of diarrhea due to verotoxinproducing Escherichia coli in the Canadian Northwest Territories. Scand J Infect Dis. 1994;26:675-84.

5. Akashi S, Joh K, Tsuji A, Ito H, Hoshi H, Hayakawa T. A severe outbreak of haemorrhagic colitis and haemolytic uraemic syndrome associated with Escherichia coli 0157:H7 in Japan. Eur J Pediatr. 1994;153:650-5. 
6. Zhang J, Xia S, Shen G, Chen Z, Huang P, Fu B, et al. A study on acute renal failure after an outbreak of diarrhea in Suixian county, Henan province. Zhonghua Liu Xing Bing Xue Za Zhi. 2002;23:105-7.

7. Munns KD, Selinger LB, Stanford K, Guan L, Callaway TR, McAllister TA. Perspectives on supershedding of Escherichia coli 0157:H7 by cattle. Foodborne Pathog Dis. 2015;12:89-103.

8. Karmali MA. Emerging public health challenges of Shiga Toxin-producing Escherichia coli related to changes in the pathogen, the population, and the environment. Clin Infect Dis. 2017;64:371-6.

9. Nguyen TD, Vo TT, Vu-Khac H. Virulence factors in Escherichia coli isolated from calves with diarrhea in Vietnam. J Vet Sci. 2011;12:159-64.

10. Garmendia J, Ren Z, Tennant S, Midolli Viera MA, Chong Y, Whale A, et al. Distribution of tccP in clinical enterohemorrhagic and enteropathogenic Escherichia coli isolates. J Clin Microbiol. 2005;43:5715-20.

11. Adamu MS, Ugochukwu ICl, Idoko SI, Kwabugge YA, Abubakar NS, Ameh JA. Virulent gene profile and antibiotic susceptibility pattern of Shiga toxin- producing Escherichia coli (STEC) from cattle and camels in Maiduguri, North- Eastern Nigeria. Trop Anim Health Prod. 2018;50:1327-41.

12. Kumarasamy KK, Toleman MA, Walsh TR, Bagaria J, Butt F, Balakrishnan R, et al. Emergence of a new antibiotic resistance mechanism in India, Pakistan, and the UK: a molecular, biological, and epidemiological study. Lancet Infect. Dis. 2010; 10:597-602.

13. Mir RA, Kudva IT. Antibiotic-resistant Shiga toxin-producing Escherichia coli: An overview of prevalence and intervention strategies. Zoonoses Public Health. 2019;66:1-13.

14. Ogden ID, Macrae M, Stechan, NJ. Is the prevalence and shedding concentrations of E. coli 0157 in beef cattle in Scotland seasonal? FEMS Microbiol Lett. 2004; 233:297-300.

15. Ni DX, Wang H, Gu L, Guo XL, Zhuang L, Shi P, et al. Surveillance of Escherichia coli 0157:H7 among animals in Jiangsu province in 1999. Zhonghua liuxingbingxue zazhi. 2002;23:102-4.

16. Ding H, Su ZQ, Xia LN, Wang YM, Wang D, Zhang JY, et al. Influence of immunomagnetic enrichment method for isolation and identification of E.coli 0157:H7 from bovine. China Animal Husbandry \& Veterinary Medicine. 2017;44: 1189-94. (In Chinese)

17. Proulx F, Seidman EG, Karpman D. Pathogenesis of Shiga Toxin-associated Hemolytic Uremic Syndrome. Pediatr Res. 2001; 50:163-71.

18. Mora A, Blanco M, Blanco JE, Dahbi G, López C, Justel P, et al. Serotypes, virulence genes and intimin types of Shiga toxin (verocytotoxin)-producing Escherichia coli isolates from minced beef in Lugo (Spain) from 1995 through 2003. BMC Microbiol. 2007;7:13.

19. Bradford PA. Extended-spectrum $\beta$-lactamases in the 21st century: characterization, epidemiology, and detection of this important resistance threat. Clin Microbiol Rev. 2001;14:933-51.

20. Kennedy CA, Fanning S, Karczmarczyk M, Byrne B, Monaghan Á, Bolton D, et al. Characterizing the multidrug resistance of non-0157 Shiga toxin-producing Escherichia coli isolates from cattle farms and abattoirs. Microb Drug Resist. 2017;23:781-90.

21. ISO 16654., 1st ed. Microbiology-Horizontal method for the detection of Escherichia coli 0157, International Organization for Standardization, Geneve, Switzerland. 2001. 
22. ISO/TS 13136., Microbiology of food and animal feed-real-time polymerase chain reaction (PCR)based method for the detection of food-borne pathogens- horizontal method for detection of Shiga toxin-producing Escherichia coli (STEC) and the determination of 0157, 011, 026, 0103 and 0145 serogroups. 2012.

23. Gannon VP, D'Souza S, Graham T, King RK, Rahn K, Read S. Use of the flagellar H7 gene as a target in multiplex PCR assays and improved specificity in identification of enterohemorrhagic Escherichia coli strains. J Clin Microbiol. 1997; 35:656-62.

24. Pollard DR, Johnson WM, Lior H, Tyler SD, Rozee KR. Rapid and specific detection of verotoxin genes in Escherichia coli by the polymerase chain reaction. J. Clin. Microbiol. 1990;28:540-5.

25. Bosllevac JM, Koohmaraie M. Prevalence and characterization of non-0157 Shiga toxin-producing Escherichia coli isolates from commercial ground beef in the United States. Appl Environ Microbiol. 2011;77:2103-12.

26. Clinical and Laboratory Standards Institute (CLSI). Performance Standards for Antimicrobial Susceptibility Testing, 26th Edn. CLSI supplement M100S. Wayne, PA: Clinical and Laboratory Standards Institute. 2016

27. Pagani L, Dell'Amico E, Migliavacca R, D'Andrea MM, Giacobone E, Amicosante G, et al. Multiple CTX$M$-type extended-spectrum $\beta$-lactamases in nosocomial isolates of enterobacteriaceae from a hospital in northern Italy. J. Clin. Microbiol. 2003;41:4264-9.

28. Saladin M, Cao VT, Lambert T, Donay JL, Herrmann JL, Ould-Hocine Z, et al. Diversity of CTX-M betalactamases and their promoter regions from Enterobacteriaceae isolated in three Parisian hospitals. FEMS Microbiol Lett. 2002;209:161-8.

29. Eckert C, Gautier V, Saladin-Allard M, Hidri N, Verdet C, Ould-Hocine Z, et al. Dissemination of CTX-Mtype beta-lactamases among clinical isolates of Enterobacteriaceae in Paris, France. Antimicrob Agents Chemother. 2004;48:1249-55.

30. Lin CF, Hsu SK, Chen CH, Huang JR, Lo HH. Genotypic detection and molecular epidemiology of extended-spectrum $\beta$-lactamase-producing Escherichia coli and Klebsiella pneumoniae in a regional hospital in central Taiwan. J Med Microbiol. 2010;59:665-71.

31. Keyes K, Hudson C, Maurer JJ, Thayer S, White DG, Lee MD. Detection of florfenicol resistance genes in Escherichia coli isolated from sick chickens. Antimicrob Agents Chemother. 2000;44:421-4.

32. Kerrn MB, Klemmensen T, Frimodt-Møller N, Espersen F. Susceptibility of Danish Escherichia coli strains isolated from urinary tract infections and bacter-aemia, and distribution of sul genes conferring sulphona-mide resistance. J Antimicrob Chemother. 2002;50:513-6.

33. Ng LK, Martin I, Alfa M, Mulvey M. Multiplex PCR for the detection of tetracycline resistant genes. Mol Cell Probes. 2001;15:209-15.

34. Carattoli A, Bertini A, Villa L, Falbo V, Hopkins KL, Threlfall EJ. Identification of plasmids by PCRbased replicon typing. J Microbiol Methods. 2005;63:219- 28.

35. Gautom RK. Rapid pulsed-field gel electrophoresis protocol for typing of Escherichia coli 0157:H7 and other gram-negative organisms in 1 day. J Clin Microbiol. 1997; 35:2977-80. 
36. Tenover FC, Arbeit RD, Goering RV, Mickelsen PA, Murray BE, Persing DH, et al. Interpreting chromosomal DNA restriction patterns produced by pulsed-field gel electrophoresis: criteria for bacterial strain typing. J Clin Microbiol. 1995;33: 2233-9.

\section{Tables}

Table 1 E. coli 0157:H7 isolates and virulence genes 


\begin{tabular}{|c|c|c|c|c|c|}
\hline $\begin{array}{l}\text { Sample } \\
\text { place }\end{array}$ & Farm & $\begin{array}{l}\text { Sample } \\
\text { source }\end{array}$ & Strain & Virulence genes & Collection time \\
\hline \multirow[t]{15}{*}{ Yili } & A & Feces & Y2-F25 & stx2 & 2013.08 \\
\hline & & & Y2-F27 & stx2 & 2013.08 \\
\hline & $\mathrm{B}$ & Feces & Y1-F166 & $s t \times 1+s t x 2+e a e+h l y+t c c P$ & 2014.08 \\
\hline & C & Feces & Y3-F328 & $s t \times 2+e a e+h l y+t c c P$ & 2014.08 \\
\hline & D & Rectalswab & Y4-A20-1 & $s t \times 1+s t x 2+e a e+h l y+t c c P$ & 2015.09 \\
\hline & & & Y4-A20-2 & $s t \times 1+s t \times 2+e a e+h l y+t c c P$ & 2015.09 \\
\hline & & & Y4-A20-3 & eae & 2015.09 \\
\hline & & & Y4-A20-4 & $s t \times 1+s t \times 2+e a e+h l y+t c c p$ & 2015.09 \\
\hline & & & Y4-A20-5 & eae & 2015.09 \\
\hline & & & Y4-A41-2 & stx $1+s t x 2+e a e+h l y+t c c P$ & 2015.09 \\
\hline & & & Y4-A41-4 & stx $1+e a e+h l y$ & 2015.09 \\
\hline & & & Y4-A103 & eae+hly & 2016.10 \\
\hline & & & Y4-A109 & $s t \times 1+s t \times 2+e a e+h l y+t c c P$ & 2016.10 \\
\hline & Slaughterhouse & Carcass swab & Y4-C21-1 & $s t \times 1+s t x 2+e a e+h l y+t c c P$ & 2015.09 \\
\hline & & & Y4-C21-2 & $s t \times 1+s t x 2+e a e+h l y+t c c P$ & 2015.09 \\
\hline \multirow[t]{8}{*}{ Wulumuqi } & E & Rectal swab & W2-A61-2 & $s t \times 2+e a e+h / y+t c c P$ & 2016.10 \\
\hline & & & W2-A61-3 & $s t \times 2+e a e+h / y+t c c P$ & 2016.10 \\
\hline & & & W2-A61-4 & $s t \times 2+e a e+h / y+t c c P$ & 2016.10 \\
\hline & & & W2-A61-5 & $s t \times 2+e a e+h / y+t c c P$ & 2016.10 \\
\hline & $\mathrm{F}$ & Feed & W1-E16 & $s t \times 1+e a e+h l y+t c c P$ & 2016.03 \\
\hline & & & W1-E50-4 & - & 2017.01 \\
\hline & & & W1-E51-3 & - & 2017.01 \\
\hline & & & W1-E51-5 & - & 2017.01 \\
\hline \multirow[t]{4}{*}{ Akesu } & G & Feces & A2-F10 & $s t \times 2+e a e+h l y+t c c P$ & 2012.10 \\
\hline & & & A2-F14 & - & 2012.10 \\
\hline & $\mathrm{H}$ & Feces & $\mathrm{A} 1-\mathrm{F} 1$ & - & 2015.09 \\
\hline & & & A1-F13 & - & 2015.09 \\
\hline
\end{tabular}

-, No virulence genes were identified in this study. 
Table 2 Information on sample collection

\begin{tabular}{lllllllll}
\hline $\begin{array}{l}\text { Source of } \\
\text { sample }\end{array}$ & NO. of farms & Feces & $\begin{array}{l}\text { Rectal } \\
\text { swab }\end{array}$ & Water & Feed & $\begin{array}{l}\text { Carcass } \\
\text { swab }\end{array}$ & $\begin{array}{l}\text { NO. of } \\
\text { positive } \\
\text { samples }\end{array}$ & $\begin{array}{l}\text { NO. of } \\
\text { positive } \\
\text { farms }\end{array}$ \\
\hline $\begin{array}{l}\text { Tacheng } \\
\text { Bole }\end{array}$ & 2 & 134 & 0 & 0 & 0 & 0 & 0 & 0 \\
Yili & 4 & 43 & 82 & 10 & 6 & 0 & 0 & 0 \\
& 1 & 480 & 397 & 42 & 29 & 0 & 8 & 4 \\
& slaughterhouse & 0 & 0 & 0 & 0 & 48 & 1 & 1 \\
Wujiaqu & 1 & 8 & 79 & 9 & 4 & 0 & 0 & 0 \\
Changji & 2 & 46 & 211 & 17 & 23 & 0 & 0 & 0 \\
$\begin{array}{l}\text { Wulumuqi } \\
\text { Akesu }\end{array}$ & 4 & 90 & 467 & 30 & 48 & 0 & 4 & 2 \\
Total & 4 & 354 & 0 & 0 & 0 & 0 & 4 & 2 \\
\hline
\end{tabular}

Table 3 Oligonucleotides of the various targeted genes 


\begin{tabular}{|c|c|c|c|c|}
\hline $\begin{array}{l}\text { Target } \\
\text { gene }\end{array}$ & Primer Sequence (5'-3') (Forward/reverse) & $\begin{array}{l}\text { Amplicon } \\
\text { size(bp) }\end{array}$ & $\begin{array}{l}\text { Annealing } \\
\text { Temp. } \\
\left({ }^{\circ} \mathrm{C}\right)\end{array}$ & Reference \\
\hline$r f b E$ & ATTGCGCTGAAGCCTTTG/CGAGTACATTGGCATCGTG & 500 & 54 & This study \\
\hline flic & GCGCTGTCGAGTTCTATCGAGC/CAACGGTGACTTTATCGCCATTCC & 625 & 58 & [23] \\
\hline stx 1 & GAAGAGTCCGTGGGATTACG/AGCGATGCAGCTATTAATAA & 130 & 54 & [24] \\
\hline stx2 & TTAACCACACCCACGGCAGT/GCTCTGGATGCATCTCTGGT & 346 & 54 & [24] \\
\hline eae & CATTATGGAACGGCAGAGGT/ACGGATATCGAAGCCATTTG & 375 & 52 & This study \\
\hline hly & CACACGGAGCTTATATTCTGTCA/AATGTTATCCCATTGACATCATTTGACT & 319 & 45 & [25] \\
\hline tcc $P$ & CGCCATATGATTAACAATGTTTCTTCAC/CTCGAGTCACGAGCGCTTAGATGTATT & 700 1000 & 58 & This study \\
\hline blacTX- & ATGTGCAGYACCAGTAARGT/TGGGTRAARTARGTSACCAGA & 593 & 50 & [27] \\
\hline \multicolumn{5}{|l|}{$\mathrm{M}-\mathrm{U}$} \\
\hline $\begin{array}{l}{ }^{\text {blacTX- }} \\
\text { M-1G }\end{array}$ & GTTACAATGTGTGAGAAGCAG/CCGTTTCCGCTATTACAAAC & 1018 & 50 & [27] \\
\hline blacTX- & ATGATGACTCAGAGCATTCG/TGGGTTACGATTTTCGCCGC & 865 & 55 & [28] \\
\hline \multicolumn{5}{|l|}{$M-2 G$} \\
\hline blactx- & ATGGTGACAAAGAGAGTGCA/CCCTTCGGCGATGATTCTC & 870 & 60 & [29] \\
\hline \multicolumn{5}{|l|}{ M-9G } \\
\hline blaTEM & ATGAGTATTCAACATTTCCGT/TTACCAATGCTTAATCAGTGA & 861 & 48 & [30] \\
\hline blasHV & CCGGGTTATTCTTATTTGTCGCT/TAGCGTTGCCAGTGCTCG & 1081 & 48 & [30] \\
\hline cmIA1 & CCGCCACGGTGTTGTTGTTATC/CACCTTGCCTGCCCATCATTAG & 698 & 59 & [31] \\
\hline sul1 & CGGCGTGGGCTACCTGAACG/GCCGATCGCGTGAAGTTCCG & 433 & 65 & [32] \\
\hline tetA & GCTACATCCTGCTTGCCTTC/CATAGATCGCCGTGAAGAGG & 210 & 55 & [33] \\
\hline tetE & AAACCACATCCTCCATACGC/AAATAGGCCACAACCGTCAG & 278 & 55 & [33] \\
\hline tetG & GCTCGGTGGTATCTCTGCTC/AGCAACAGAATCGGGAACAC & 468 & 55 & [33] \\
\hline
\end{tabular}

\section{Figures}




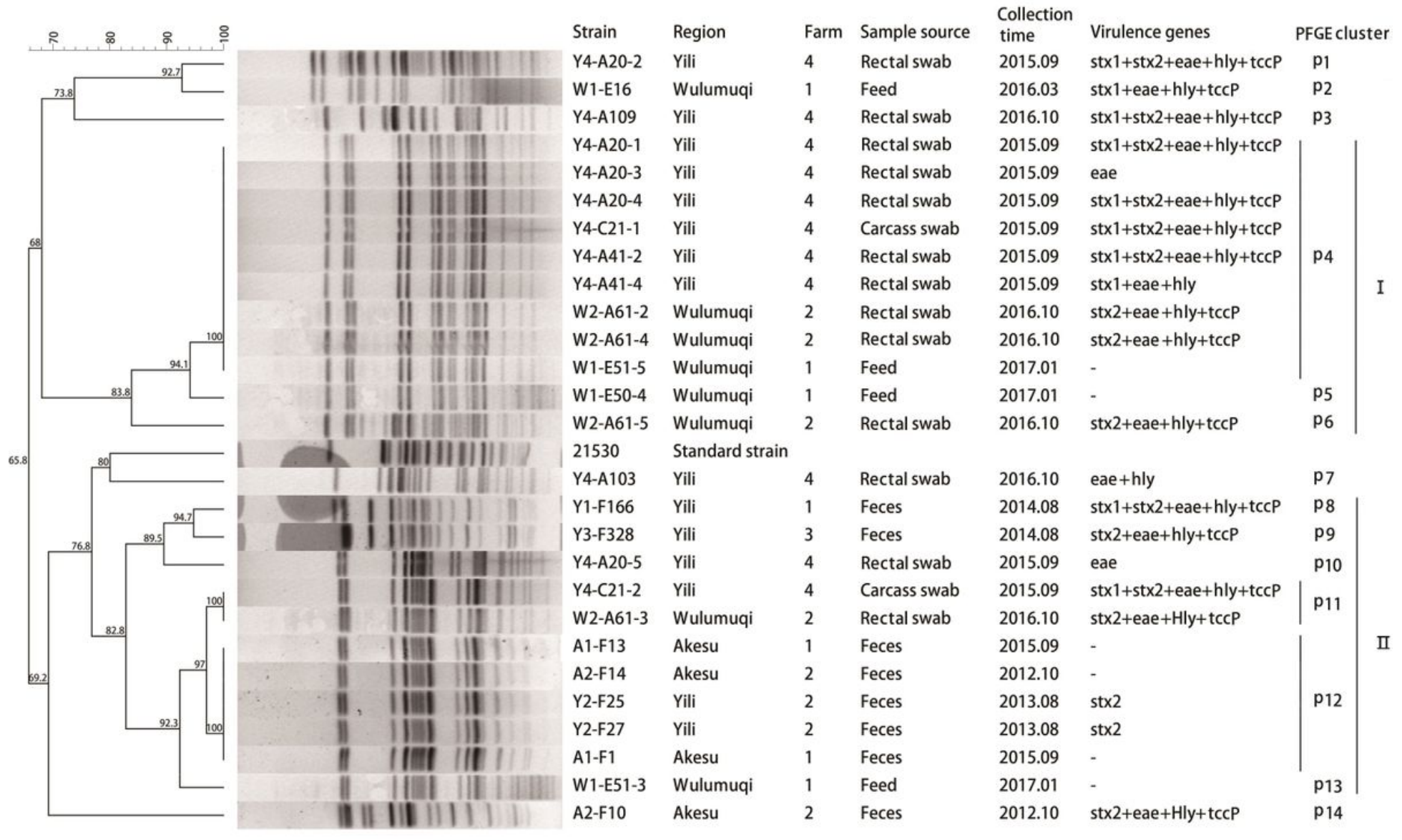

Fig. 1 Dendrogram of $X b a \mathrm{I}$ pulsed-field gel electrophoresis profiles of O157:H7 isolates.

Figure 1

Dendrogram of Xbal pulsed-field gel electrophoresis profiles of E.coli 0157:H7 isolates 